\title{
Incidence and Impact of Bullying on Secondary and Higher Secondary Government-Aided School Students of Noida, UP
}

\section{Iram Shamim Malik* and Sana Ahmed*}

B.Ed. Semester III, Amity Institute of Education, Amity University, Uttar Pradesh (AUUP), India

"Corresponding author: iram.shamim2003@gmail.com / sana100ahmed@gmail.com

\begin{abstract}
During the school years, bullying is one of the most common manifestations of violence. Research on bullying started more than 40 years ago where Olweus (1973) defined this behaviour as aggressive and intentional act carried out by a group or an individual repeatedly and over time against a victim who is in some way smaller, weaker, younger or in any way more vulnerable than the bully. There are different forms of bullying with the behaviours including but not limited to- verbal abuse, intimidation, blackmail, physical coercion, harassment and threats. The main reasons of bullying are the differences in race, class, sexual orientation, language, size, reputation and the ability of an individual. It hampers learning and development, robbing the child of his/ her self-esteem and confidence to face others and develop as an individual. Intensive school-based programs against bullying, disciplinary methods and the mobilization of bystanders, or the silence of the majority witnessing bullying, are keys to success. The authorsaim to scrutinize the incidence of bullying among secondary and highersecondary students of a government-aided all-girls school of Noida, UP through a self-administered questionnaire on a sample size of 100 students. They also aim to understand the students' perspective of the reason behind being bullied and what according to them can be done by the adults to curb it. The paper intends to ascertain the impact that bullying poses on the students by instilling fear and anxiety in them and also whether students feel free to talk about it with others.
\end{abstract}

Key words: Students, Bullying, Different forms, Incidence, Impact, Hampers learning, Adults, By-standers, Mobilization

Over the last 30 years, bullying among children and adolescents has been the focus of many international studies. Norwegian Scholar Daniel Olweus is considered the founding father of 
anti-bullying research,who started a 'Bullying Prevention Program' after three boys between the age groups of 10-14 years committed suicide out of extreme harassment from classmates in the year 1982. According to him, bullying occurs when a person by repeated exposure to aggression and negative actions and when the victim is unable to protect himself or herself. Allison (2014) defines bullying as the intentional use of force, threat, intimidation and aggressive behaviour against others to dominate and control them. It involves a real or perceived power imbalance which the bully recognizes and exploits in the form of harassment. Bullying can be physical, verbal, or nonverbal or psychological, anything from making gestures to deliberately excluding someone from a group. The latter form of bullying, known as indirect bullying, is difficult to spot but uses dangerous social isolation as a weapon. Some of the recent studies illustrate several detrimental effects of bullying on the mental health besides heavily impacting students' academic outcomes. This isn't just limited to the ones who are bullied but the bullies are equally affected as well. Students often hide their bullying experiences with the adults which would go on if no action is taken. Victims of bullying could suffer from depression, anxiety, psychosomatic disorders, suicidal tendencies or poor academic performance. Others in the classroom or school environment, known as bystanders, are impacted with feelings of fear, apprehension, and stress. If bullying isn't timely addressed, bullies could resort to criminal behavior and drug abuse. Olweus claims that by the time bullies are 24 years old, $60 \%$ of them would have indulged in some or the other criminal activity.

The first line of defense measure against a bully is avoidance. Being smart is to walk away from a bully without confronting him/her. A second measure is to have a companion around as bullies usually don't pick on people who are surrounded by friends. Parents and adults have a huge role to play in protecting their children from bullying by boosting their selfconfidence. Besides this, they should regularly ask their children how peers treat them.

\section{Statement of the problem}

This study has been conducted as a response to the episodes of bullying witnessed by the researchers among secondary and higher secondary students in a government-aided all-girls school of Noida. Through this study, the researchers intend to sensitize the students about bullying and learn about the frequency of students getting bullied, witnessing bullying and bullying others, fear developed due to bullying, whether they have been made conscious about it by an adult before and what according to them the adults should do to stop it and how open are the students to talk about it with others.

\section{Research questions}

The researchers have attempted to explore and identify rate of bullying in the school, its impact on the students and its causes by asking questions to the students about: 
Incidence and Impact of Bullying on Secondary and Higher Secondary Government... . P

1. Frequency of getting bullied.

2. Frequency of watching others getting bullied.

3. Frequency of missing school due to feeling unsafe, uncomfortable and nervous.

4. Number of times the students felt afraid of being pushed, slapped, hit or kicked in school.

5. Number of times they have been afraid of their property getting stolen or vandalized.

6. Students' perspectives of the reasons behind getting bullied.

7. Number of time the students themselves bullied others.

8. If they were ever sensitized about bullying by any adult.

9. Students' opinion about the ways the adults can contribute to stop bullying.

10. Who they talk to about being bullied?

\section{Objectives of the study}

1. To estimate the incidence of bullying among the secondary and higher secondary school students.

2. To identify the impact of bullying amongst the students.

3. To discern the students' outlook of the factors responsible for bullying.

4. To determine their expressiveness about bullying.

\section{Significance and Scope of the study}

Having observed secondary and senior secondary girls, bullying each other in the classrooms, the author felt the dire need to educate the students about bullying and to learn about its incidence, causes and impact on the students. The authors felt the need to address this issue as bullying has an adverse effect on children's mental and emotional health, quality of life and academic performance. Secondary or higher secondary school could be the last opportunity at the hands of the teachers towards shaping the character of the students. For some students this may be the last opportunity for an intervention to change behavior before they become adults and merge with the people in the workplace or with the community at large. Thus, the authors realized that it is incumbent for the students to be fully aware about this problem and to keep all channels of communications open to discuss with family, friends and teachers to avoid suffering as a silent victim, ever.

This study will deepen the understanding of the researchers about the bullying behavior and its impact on the secondary and higher secondary level girls and how open they are to discuss about bullying with people around them. Since bullying happen when adults are 
\%

Malik and Ahmed

not around and students rarely share the bullying incident, adults often underestimate the rates of bullying. Assessing bullying through this study can provide a clear picture of what is going on. This study would open doors for the appropriate prevention and intervention strategies based upon the results obtained. Identifying the incidence of bullying and students' attitudes towards it is the preliminary step towards controlling bullying and this study would be a pertinent way to do it. Also, the results of this study can be used and referred to, in any future researches on bullying.

\section{Delimitation of the study}

This study has included only one school with a small sample size of 100 which cannot represent all the secondary school students of India. Also the school selected for the current study is all-girls school which doesn't represent students from both the genders. Thus, these factors serve as important delimitations of this study.

\section{Review of literature}

According to Moon (2008), bullying is a problem of worldwide importance and negatively influences the overall school climate and endangers the right of students to study in a safe environment free of any threats. Simmons claims that bullying happen most frequently in elementary schools and goes down in middle school year but again escalates during high school years.

\section{Incidence of bullying and kinds of bullying experiences among secondary and higher secondary school students}

Jones et al. (2008) reported a study done by World Health Organization (2004) that revealed that more than one-third students who were found to be bullied, $28 \%$ of them declared that they were kicked, pushed, hit, shoved or locked indoors. Boys that constituted around 35.8\% reported more about these physical bullying episodes than the girls (22.2\%). A study was conducted by Amadi and Thunwo (2018) to determine the prevalence of bullying among 3 secondary schools in Obio/Akpor Local Government Area of Rivers State, Nigeria. The findings demonstrate that though more girl students are bullied than the boy students but its boys who outrank girls in terms of bullying others. Forming cliques, name calling, pushing and ridiculing were among the most common forms of bullying. The results also revealed that students who are victims of bullies often didn't share their experiences but sometimes shared with their friends. A study was conducted by Alex-Hart et al. (2015) to determine the prevalence and kinds of bullying in a secondary school of Port Harcourt. This cross-sectional study was conducted upon 1160 students from three schools- 2 schools, 2 all-boys schools and 2 all-girls school. The findings demonstrated that bullying was higher in all-boys (90.8\%) and 
all-girls (82.9\%) school when compared with mixed schools (73.5\%). Physical bullying came out to be the most common type of bullying accounting for $57.5 \%$ of all kinds.

In another study done by Turkmen et al. (2013), the prevalence, victims, types and places of bullying was identified on students between 14-17 years of age in Bursa, Turkey. The result declared that chance of male students indulging in a bullying behavior was 8.4 times higher than that their female counterparts. Tural \& Tural (2018) in their research involving 1375 high school students identified some risk factors associated with bullying behavior. These included students with consistent lower grades, students with low entrance score, being a male student and belonging to a class with lesser number of girls than boys. The study led by Owuamanam (2015) disclosed that emotional form of bullying was amongst highly experienced type of bullying and boys had suffered bullying as well as displayed bullying behavior more than the girls.

\section{Impact of bullying on academic performance}

According to Ballard et al. (1999) victims of bullying often fail to concentrate in their studies and their academic performance declines. Al-Raqqad et al. (2017) asserts that bullying at schools deeply affects the academic performance of not just the victims of bullying but the bullies as well. Victims of bullying experience difficulty in adjusting in the school environment, feel detached and lack sense of belongingness to the school and some of them also feel terrified of going to school. According to Hemphill et al. (2011) being a victim of bullying leads to depression, school avoidance and poor attendance which eventually cause poor academic performance. Another study done by Chandran et al. (2018) reveals that bullying has a negative impact on the academic performance of the victims of bullying but has a positive impact on the academic performance of the bullies.

\section{Necessary measures to control bullying}

Following are some of the important measures suggested by Amadi and Ihunwo (2018) that should be taken proactively by the school teachers and school authority to control the occurrence of bullying in schools:

1. School teachers should familiarize the students about bullying behavior and bullying related activities by means of organized gathering.

2. Schools should have well qualified counselors in place to cater to the bullies as well as the bullied.

3. Schools should have an online platform for interaction between teacher, students and parents in an effort to control bullying.

4. Strict actions should be taken against the bullies whenever any bullying incidence is reported to the school teachers or the authority. 
5. There should be complaint boxes at several places in the school campus and informants should also be allotted who would stay in touch with the teachers and counselors.

To improve the academic performance of the students degraded due to the impact of bullying, students should be made to participate in more and more extra-curricular activities. Ample facilities to involve in extra-curricular activities should be provided by the school to the students.

\section{Research methodology}

The current study was conducted on 100 students of a government-aided all-girls school of Noida, UP. Samples were selected through simple random sampling and they ranged between classes $9^{\text {th }}$ to $12^{\text {th }}$. The researchers first inspected the familiarity of the students with the term 'bullying.' A power-point presentation was shown to sensitize the students about the topic. This was done in 4 batches, each of 25-30 students. Following this, questionnaire as a research tool was administered on the students.

\section{Presentation, interpretation and analysis of findings}

\section{During this school year how often students have seen someone being bullied?}

Answer: 22\% responded that they have never seen someone being bullied during this school year, $55 \%$ replied that they have seen someone being bullied occasionally ( 1 or 2 times a month), $15 \%$ answered that they have seen someone being bullied regularly ( 1 or 2 times a week) whereas $8 \%$ reported that they have seen someone being bullied daily.

Analysis: As it can be seen from the data that more than $75 \%$ of the respondents witnessed incidents related to bullying, which makes it an area of concern for the schools to put adequate measures in place to check the menace of bullying and ascertain that kids are not prone to it.

\section{During this school year how often student have been bullied at school?}

Answer: $70 \%$ reported that they were never bullied during this school year, $26 \%$ responded that they were bullied sometimes ( 1 or 2 times a month) whereas $4 \%$ reported that they were bullied regularly ( 1 or 2 times a week).

Analysis: In this survey we could gather that students most likely don't report bullying or accept that they are bullied which makes it difficult for the management and teachers to address it.

\section{During this school year how often student felt unsafe, uncomfortable or nervous at school or on the way to or from school?}

Answer: $72 \%$ responded that they never felt unsafe at school or on the way, $24 \%$ reported that they felt uncomfortable sometimes, whereas $4 \%$ felt unsafe regularly. 
Incidence and Impact of Bullying on Secondary and Higher Secondary Government... . P

Analysis: Majority of the students felt safe and secure while commuting to the school and within the school premises. A little over quarter of a respondent felt uncomfortable and unsafe which provides a succour to thought that safety of students should be the utmost priority of the management.

\section{If the students have been bullied, why do they think it happens?}

Answer: $71 \%$ answered that they are not being bullied at all, 13\% responded that they have no idea why they are being bullied, 3\% reported that they are being bullied because they act or look different, 3\% responded that they are being bullied as they always do well in class, 5\% replied that they are being bullied because they are smaller or weaker, whereas 5\% reported that they are being bullied as they deserve it.

Analysis: Most of the students are either not bullied, or they have concealed the fact that they are bullied, also in majority of the cases they were unaware of the reasons of getting bullied.

\section{How many times during this school year have students bullied, teased or made fun of someone?}

Answer: 65\% replied that they have never bullied, teased or made fun of someone, $28 \%$ reported that they have sometimes teased and made fun of someone (once or twice a month), 4\% answered that they bully someone regularly (once or twice a week) whereas 3\% responded that they bully someone every day.

Analysis: Majority of the students declined to have bullied others, some of them they agreed to mild bullying or making fun of others.

\section{How many times during this school year students have been afraid of being pushed, shoved, slapped, hit or kicked by someone on school property?}

Answer: 73\% answered that they have never been afraid of being pushed, shoved, slapped, hit or kicked by someone on school property, 20\% reported that they have been afraid sometimes (once or twice a month) whereas 7\% have reported that they have been afraid of being pushed, hit or kicked by someone regularly (once or twice a week).

Analysis: Most of the times students are not scared of being handled physically within the school campus, still almost quarter of the students are still prone of physical assault which is an area of concern for the authorities.

\section{How many times during this school year have you been afraid of having your property stolen or deliberately damaged?}

Answer: 50\% students responded that they have never been afraid of having their property 
P

Malik and Ahmed

stolen or damaged, $42 \%$ replied that their property was stolen or damaged sometimes (once or twice a month), $6 \%$ answered that their property was stolen or damaged on a regular basis (once or twice a week) whereas $2 \%$ reported that their property have been stolen or deliberately damaged daily.

Analysis: Misplacing or stealing of articles within the school campus is a regular feature as we witnessed during the survey. The opinion was divided which provides an area of concern to be dealt properly.

\section{Has an adult at school talked to your class about bullying ?}

Answer: $64 \%$ responded that no adult have talked to the class about bullying, 23 replied that an adult once talked to them about bullying and what they said helped them a lot, $13 \%$ reported that an adult once talked to them about bullying but they don't really understand what is going.

Analysis: Majority of the students didn't get any hand-holding with regards to the bullying menace.

\section{What can adults at school do better to help stop bullying?}

Answer: 14\% suggested that adults should supervise the school better, $48 \%$ proposed that adults should make rules against bullying and discipline bullies, $16 \%$ put forward that adults must talk about bully prevention in class, $15 \%$ advised that adults should help students work problems out whereas $7 \%$ advocated that bullying is not a problem at their school.

Analysis: Majority of the respondents feel that drafting rules and regulations to stop bullying will be an effective measure to counter it whereas some feel that adults should carry out their responsibility properly by educating the kids about bullying and giving them proper advice and safeguards to handle such a situation.

\section{Have students talked to anyone about being bullied?}

Answer: $40 \%$ students reported that they have not being bullied at all, 20\% replied that they haven't talked to anyone about bullying, $7 \%$ responded that they have talked to teacher or other adult at school, $8 \%$ have talked to their siblings, 15\% to their friends whereas $10 \%$ have talked to their parents about being bullied.

Analysis: We have noticed that students are hardly vocal about being bullied, which makes it difficult for the parents and teachers to place the checks.

\section{CONCLUSION}

The research points at some very pertinent questions, which are of prime concerns and need to get addressed in order to provide safe and conducive environment within the school 
Incidence and Impact of Bullying on Secondary and Higher Secondary Government... .

premises to ascertain that students are not victimized and their psyche is not affected. Most of the students are vulnerable to bullying and in absence of proper education and advice about countering this menace, they find themselves at an uncomfortable situations. They don't even report bullying most of the times but somewhere inside they get affected which in turn develop complex and challenge their creative skills. Thus it is very necessary that parents and teachers both should educate the kids about bullying and provide them with adequate measures so that if they are subjected to it then they know how to counter it.

\section{REFERENCES}

Alex-Hart, B. A., Okagua, J. and Opara P.I. 2015. Prevalence of bullying in secondary schools in Port Harcourt. International Journal of Adolescent Medical Health, 27(4): 391-396.

Allison, S., Roeger, L., Smith, B. and Isherwood, L. 2014. Family histories of school bullying: implications for parent-child psychotherapy. Australasian Psychiatry, 22(2): 149-153.

Al-Raqqad, H.K., Al-Bourini, E.S., Al-Talahin, F.M. and Arank, R.M.E. 2017. The impact of school bullying on students' academic achievement from teachers' point of view. International Education Studies, 10(6): 44-50.

Amadi, G.N. and Ihunwo, P.C. 2018. Prevalence of bullying among secondary school students: A case study of three schools in Obio Akpor Lga of rivers state. International Journal of Multidisciplinary Research and Development, 5(7): 20-25.

Ballard, M., Tucky, A. and Remley, T.P. 1999. Bullying and violence: A proposed prevention programme. NASSP Bulletin, pp. 38-47.

Bradshaw, C.P. 2014. The role of families in preventing and buffering the effects of bullying. Journal of the American Medical Association Pediatrics, 168: 991-993.

Buck, S. 2017. After three boys committed suicide in 1982, this doctor founded a heroic anti-bullying program. Retrieved fromhttps://timeline.com/dan-olweus-bullying-prevention-8fa8f7983c97.

Chandran, R., Namboodiripad, K. and Madhavan, V. 2018. Bullying and academic performance among school children. International Journal of Pure and Applied Mathematics, 118(5).

Hemphill, S.A., Kotevski, A., Herrenkohl, T.I., Bond, L., Kim, M.J., Toumbourou, J.W. and Catalano, R.F. 2011. Longitudinal consequences of adolescent bullying perpetration and victimisation: A study of students in Victoria, Australia. Criminal Behaviour and Mental Health, 21(2): 107-116.

Jones, N., Moore, K., Villar-Marquez, E. and Broadbent, E. 2008. Painful Lessons: The Politics of Preventing Sexual Violence and Bullying at School-Working. Paper 295. London: Overseas Development Institute and Plan International.

Moon, B., Hwang, H.W. and McLuskey, J.D. 2008. Causes of school bullying. Crime and delinquency. Vol. XX Number $X$ Sage publication. Retrieved from http://cad.sagepub.com.

Muli, M., Nzoka, Muthee, J. 2019. Prevalence of Bullying Behavior on Academic Performance among Students in Integrated Public Secondary Schools in Kitui County, Kenya. International Journal of Research and Innovation in Social Science, 3(9).

Newman, S. and Golden, B. 2016. Bullying. Retrieved from https://www.psychologytoday.com/us/basics/bullying.

Olweus, D. 1993. Bully/Victim problems among school children: Long-term consequences and an effective intervention program. Aggressive Behviour: Current Perspectives (pp. 97-130). New York: Plenum. 
P) Malik and Ahmed

Owuamanam, D.O. 2015. Prevalence of bullying among secondary school students in Ondo state, Nigeria. European Scientific Journal, 11(20).

Sampson, R. 2002. Bullying in school. Problem-oriented guides for police; Problem- specific guides series. No. 12. U.S Department of Justice. Retrieved from http://www.cops.usdoj.gov.

Tural, M. and Tural, M.K. 2018. Peer bullying prevalence in secondary education and its relation with High school entrance scores. Retrieved from https://www.researchgate.net/publication/326822881_Peer_bullying_prevalence_in_ secondary_education_and_its_relation_with_High_school_entrance_scores.

Türkmen, D.N., Dokgöz, M.H., Akgöz, S.S., Eren, B.N., Vural, H.P. and Polat, H.O. 2013. Bullying among High School Students. Maedica (Buchar), 8(2): 143-152. 